\title{
FROM COUSIN JOE TO THE COMOROS: ORTHOGRAPHY AND THE POLITICS OF CHOICE IN AFRICA AND AFRICAN AMERICA
}

\section{Harriet Joseph Ottenheimer Kansas State University}

This paper explores issues of orthographic representation in two different projects, in two different locations, and draws some general conclusions about the role of an outsider linguistic anthropologist in working with individuals and their data. One project involved helping Cousin Joe, a blues singer from New Orleans, to edit his autobiography for publication. The other project involved developing a bilingual, bidirectional, Shinzwani-English dictionary for the Comoro Islands. Each project required an awareness of-and sensitivity to-the cultural and political implications of orthographic decisions.

\section{Cousin Joe:}

I began working with Cousin Joe when I was doing dissertation research on blues singing in New Orleans in the 1960s. He became one of my most trusted teachers on the subject, patiently explaining things and helping me to make contact with other 
blues singers. His interest in my own project was paralleled by his concern for a project of his own: He wanted to publish his autobiography, and he offered me a bargain. He said something like, "I'Il help you work on your book if you'll help me work on mine." I agreed and we began taping narratives for his book in the winter of 1966. We continued, intermittently, until 1986, when the manuscript went to press.

Knowing that transcripts are always "intrinsically incom-

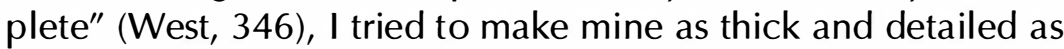
I could. I included every cough, laugh, pause, and false start and I wrote as much dialect as I heard. (See especially Preston 1982 and Edwards 1992 for comments on writing dialect). If I heard "gonna," I wrote "gonna," not "going to"; if I heard "no mo," then that is what I wrote and not "no more" or "any more."

Transforming my "basic transcripts" (Ochs 1979) into manuscript form, I smoothed out the false starts, removed the references to coughs and laughs, and underlined or italicized stressed words. (See Tedlock, 1983 and Edwards 1992 on including and marking emphasized words.) [Joe's narrative style was such that many episodes were narrated more than once, sometimes as the focus of a story and sometimes as background information for another episode. Comparing multiple narrations of the same episode I combined words and phrases from different narrations until each episode seemed clear.] I kept Joe's voice in my head as I worked.

Although representing African American speech in dialect spelling was still common in those days, I had been sensitized to the issues involved when Danny Barker, a close friend of Joe's, and a member of Cab Calloway's band had shared his own manuscript--a history of jazz--with me. Complaining that publishers had asked him to write in dialect, he had refused to do so because he regarded dialect spelling as demeaning. In spite of this I was sure that Joe's reading audience would expect some dialect. The question was how much? Joe's own approach to performance was complexly multi-layered, and he often used exaggerated dialect to mock both himself and his audience. Interpreting an audience's expectations and then playing into (and playing with) the role you think it expects requires a skillful balance of reality and pretense and Joe seemed to have mastered 


\section{Ethnic Studies Review Volume 26: 2}

the art. Since Joe used dialect a lot in his taped narrations, I began using dialect spelling throughout the manuscript. As I completed each chapter I sent it to Joe for approval. In return I received encouraging phone calls. "It's great!" he'd say.

One day, however, I was transcribing a tape that Joe had sent me, and I couldn't hear some names clearly enough, so I mailed him a copy of the rough transcript and scribbled something in the margins like "Who is this?" Joe not only sent the transcript back with the names written in but with additions and corrections. I am not sure whether it was my own handwriting on the typed page or the overall rough appearance of the transcripts that triggered this response. In any case it was a welcome change. Joe smoothed out false starts and removed references to coughs and laughs. Most importantly he substituted standard spellings for some dialect spellings: where he was narrating he used standard spellings; where he was quoting he left dialect spellings.

Going back to the tapes I could hear Joe deliberately shifting styles, using one voice ("his own") for narratives and other voices (exaggerated dialects) to depict people speaking. In some cases the tone seemed to be folksy and intimate; in others the tone seemed demeaning (even self-demeaning). As Preston says, "Non-standard spellings generally have as their primary effect on the reader a demotion of opinion of the speaker represented" (Preston, 323). But this is how Joe seemed to want it. Following his lead I began switching between standard and non-standard spelling, using non-standard spelling where Joe used exaggerated dialect and marking those sections with quote marks. Joe, as narrator, now appeared in standard spelling while most of the characters he encountered appeared in non-standard spelling. The result was that the complex, multi-layered, performances I had witnessed in New Orleans began to appear on the printed page. We finally had achieved a balance that worked and was sensitive to Joe's orthographic concerns.

Using standard spelling made it easier, in fact, for readers to hear Joe's voice as they expected to hear it. Using non-standard spelling probably helped them to imagine his characters as he wanted them to be imagined. Some quotes from reviews suggest that the strategy worked. In The [London] Sunday Times Eric 
Hobsbawm (1988) called Cousin Joe's narrative "disarming." In Living Blues John Brisbin (1989) described "Cousin Joe's effervescence" and "skill as a storyteller" calling the narrative "buoyant" and "colorful." In The Black Perspective in Music Eileen Southern (1989) commented that Joe's descriptions seemed "intensely personal."

In retrospect I find it intriguing that Joe and I never actually had a conversation about spelling. My guess is that I assumed it was my job to make initial decisions and that I expected him to make changes and comments on the manuscript, that together we would fine-tune the manuscript until it was the way he wanted it. Questions of differential power in racist New Orleans did not occur to me in this process. Somehow I had assumed that our differences in race and education were cancelled by our differences in age and gender. In addition I was his student as well as his "editor" which placed him in a position of greater authority, I thought. [He even taught me how to survive as a black person in New Orleans, a skill I found myself needing personally on occasion.] I had brought all of my linguistic anthropological skills to the collaboration, but it wasn't until we began communicating on paper about orthographic choices that we were able to achieve the results that both of us wanted.

\section{The Comoros:}

In the Summer of 1967 I put my initial Cousin Joe materials into a box in my parents' basement and headed for the Comoro Islands between Madagascar and Mozambique in the western Indian Ocean. My husband, Martin Ottenheimer, was doing his dissertation research there. He had been an occasional field assistant to me in New Orleans, fishing with Cousin Joe and accompanying me to special events. I planned to return the favor by serving as a field assistant to him. I brushed up on my French; he learned Swahili, and we took off.

We found a place to live in a town on the island of Nzwani, one of the four islands in the Comoro archipelago and soon discovered that very few Wanzwani spoke French and even fewer knew any Swahili. The local language, Shinzwani, is a Bantu language and a member of the Swahili group, but with no adequate contact language, no dictionary, and no grammar, our 


\section{Ethnic Studies Review Volume 26: 2}

context for learning it was going to be largely monolingual. I began recording the language in as much detail as I could using phonetic transcriptions until I had the phonological system worked out.

Shinzwani has been written locally for hundreds of years using Arabic script. Because every child attends Koranic school, literacy in Shinzwani is at least 90\% (Ahmed-Chamanga \& JG 1977:46). Shinzwani has more phonemes than Arabic, however, and so certain compromises have to be made. The Arabic letter ' $k$ ' $\left(\_\right)$for example, is used for both $[k]$ and $[g]$. The Arabic letter_j_ $(\tilde{A})$ is used for both [dZ], as in English 'judge' and [Z], as in English 'rouge.' There are no fixed conventions, and each individual is left to himself or herself to decide how best to write (and read) Shinzwani using Arabic characters.

With the advent of French colonialism in the 1800 s some planters and government officials began to use French to write personal and place names but for the most part French spelling was not widely used by Wanzwani. French did not fit Shinzwani much better than Arabic did, although it did have separate letters to represent $[\mathrm{k}]$ and $[\mathrm{g}]$ and $[\mathrm{Z}]$. To represent [dZ] the French used the letters 'dj.'

Taking Swahili as a model, I developed a phonemic orthography for Shinzwani which used standard Latin characters, avoiding diacritics and special ipa characters. (See Powers 1990 for comments on native reactions to diacritics.) I used the letters 'sh' to represent [S], as in English 'sheesh,' for example, and paralleled it with the letters ' $z h$ ' for [Z], which did not exist in Swahili. I trained a few lycee students in the orthography and put them to work transcribing tape-recordings of folktales, historical narratives, and interviews.

$\begin{array}{ccc}\text { EX: Ways of writing } & {[d Z]} & \text { and } \\ \text { Arabic } & \tilde{A} & \tilde{A} \\ \text { French } & d j & j \\ \text { English/Swahili } & j & \text { zh }\end{array}$

[Z]

In the 1970s when the Comoros gained their independence from France, a few young Comorian intellectuals suggested that the Comoros needed a new Latin-based orthography. (Ahmed- 
Chamanga 1976). Such a move would symbolize breaking free from French colonial influence. French spelling might be appropriate French, they argued, but the Comoros should have their own orthography, and it should resemble that used in other independent African nations. The proposed orthography looked a lot like what I had taught the Wanzwani students to use in the 1960s. The differences are interesting.

The sound [S] would now be spelled with the letters ' $s h^{\prime}$ as in Swahili, rather than with the letters ' $\mathrm{Ch}^{\prime}$ as in French. But the parallel sound $[Z$ ] would continue to be spelled with the letter ' $j$ ' as in French. And [dZ] would thus have to continue to be spelled with the letters ' $d j$ ' as in French, rather than with the letter ' $j$ ' as in Swahili and English. The fact that French rather than Swahili [or English] spellings were chosen for these two sounds reflects in part the continued influence of French-based education in the Comoros. Additionally, however, it is possible that use of the letter ' $j$ ' for [ $Z$ ] also signaled an ambivalence towards being seen as "African." In any case the orthography was adopted only by those few individuals who had been educated in French-style local schools, and most others continued using Arabic script. Since nothing was settled, I continued using my own orthography for [dZ] and [Z] in my own work.

The Shinzwani-English dictionary had begun as a paper slip file in the Comoros designed primarily for analytical purposes. In the 1970s in Kansas I copied the words from the slip file into a small loose-leaf notebook, and as I continued translating field notes and narratives I added more words to the notebook. By 1982 I had six notebooks and about 6,000 dictionary entries. I also had an English-Shinzwani index. I photocopied the whole thing, wrote up a chart of noun classes and concords, and took it to the Comoros. I was stunned by the reaction. The most common comment I heard was something like, "We really do have a language (or a grammar)!" The French told us we just spoke gibberish (or we had no grammar or we didn't have a real language)." Many individuals (including some Comorian government officials) urged me to consider publishing the dictionary.

Soon after the Comorian government commissioned a linguistic study designed to develop a Latin-based orthography for Comorian and to "increase literacy" in the Comoros. The result- 


\section{Ethnic Studies Review Volume 26: 2}

ing orthography (Cheikh, 1986a and b) was similar to the ones proposed in the 1970s. It resembled Swahili, but it used French spellings for sounds not present in Swahili. For Shinzwani this meant that the letter ' $j$ ' would continue to be used for $[Z]$, and the letters ' $d j$ ' would be used for [dZ].

As I followed the gradual acceptance of Latin-based orthography in the Comoros, it became clear that the French spellings of $[\mathrm{dZ}]$ and $[\mathrm{Z}]$ were catching on in spite of whatever post-colonial implications they might carry with them. Although I had felt that using English spellings would represent Shinzwani more clearly to English readers, I became more and more concerned that by continuing to use English spellings I would be imposing my own sense of "accuracy" on Shinzwani orthography. As Bill Powers recently wrote, "Any attempt to [impose linguistic rigor on native languages] should be seen as another form of patronization as well as linguistic hegemony.... The politics of orthography is not a theoretical idea, it is a reality, one which must be understood and assessed by all those involved with native languages" (Powers 1990:497).

Taking a lesson from the Cousin Joe project, I decided to put the question of how to use the letter ' $j$ ' to Shinzwani speakers. By now nearly all Wanzwani have completed at least eight years in local French style schools; many have completed lycee, and some have studied (or are currently studying) abroad. The discussions were interesting. Most people responded by saying that it really didn't matter since they were used to reading so many different languages and spellings. If you would just indicate somewhere what symbols were to stand for what sounds, they would adjust as necessary. Pushed to think about what they would really want to see and use and how they really would want to have the language look on the printed page, individuals felt that even if using the letter ' $j$ ' for [Z] was French, they were so used to it by now that perhaps they should continue using it that way. I also think that now, some twenty years after independence, the need to express separation from French influence is less immediate. In fact using a bit of French spelling implies that you have been educated in French style schools and can read French with all the associated status implications. I also decided to ask some English speakers such as a few of the Peace 
Corps volunteers in the Comoros and some American students in Kansas. Here too, although the initial preference was for using the letter ' $\mathrm{j}$ ' as in English the final preference was for using it as in French in part to avoid confusion with existing informal orthographic practice (otherwise you would always need a key to know how to read the letter ' $\mathrm{j}$ ') and in part because, as one Kansas student said, "If you know you are dealing with a Frenchinfluenced country, you kind of expect to see some French spelling." So the dictionary will use the letter ' $j$ ' for [Z] after all, and I am looking forward to knowing how it will be received by professionals and lay readers of both languages.

Comparing these two projects provides important insights into orthography and the politics of representation. In both cases I had thought that it was important to represent the language in question as accurately as possible in order to reach the widest audience possible. In both cases it became clear that it is even more important to respect the preferred usage of the individuals whom you are trying to represent, and that readers will make--in fact generally prefer to make--the necessary adjustments. The decisions we make, in representing individuals and their language, have far-reaching implications. Understanding these implications and discussing choices with the individuals being represented is essential. It is also important to maintain a clear distinction between basic transcription and orthographic representation. Data will always need to be transcribed with as much accuracy as the ear permits. Orthographic representation, on the other hand, must be established in response to the concerns of subject, audience, and politics. The responsible linguistic anthropologist must fully understand these variables in order to develop effective and appropriate orthographic conventions.

\section{Note:}

An earlier version of this article was presented at the 1997 meeting of the American Anthropological Assocation for the special panel on Orthography and the Politics of Representation 


\section{Ethnic Studies Review Volume 26: 2}

\section{References}

Brisbin, John. 1989. Review of "Cousin Joe: Blues from New Orleans." Living Blues, July/August 40-41.

Ahmed-Chamanga, Mohamed. 1976. Proposition pour une ecriture standard du Comorien. Asie du Sud-Est et Monde Insulindien, 7(23):73-80.

Ahmed-Chamanga, Mohamed and Noel Jacques Gueunier. 1977. Recherches sur l'instrumentalisation du Comorien: les problemes de graphie d'apres la version Comorienne de la loi du 23 Novembere 1974. Asie du Sud-Est et Monde Insulindien, 8(3-4):45-??.

Ahmed-Chamanga, Mohamed and Noel Jacques Guenier. 1977 Recherches sur I'instrumentalisation du Comorien: problemes d'adaptation lexicale (d'apres la version comorienne de la loi du 23 novembre 1974). Cahiers d'etudes Africaines, 17(2-3):213-239.

Cheikh, Moinaecha 1986a. Essai d'orthographe du comorien. Mimeographed paper, Linguistic Department, Centre National de Documentation et de Rtecherche Scientifique (CNDRS), Comoro Islands.

Chekh, Moinaecha 1986b. Exposes presente par Mme CHEIKH Moinaecha sur l'initiation a la transcription de la langue comorienne, suivis des syntheses des travaux de groups. Pp 45-84 of mimeographed study conducted at CNDRS, Comoro Islands.

Edwards, Jane Anne. 1992. Transcription of Discourse. In International Encyclopedia of Linguistics, edited by William Bright, vol. 1, pp. 367371. New York and Oxford: Oxford University Press.

Gumperz, John J. and Norine Berenz. 1993. Transcribing Conversational exchanges. in Talking Data: Transcription and Coding in Discourse Research, edited by Jane A. Edwards and Martin D. Lampert, chapter 4, pp. 91-121. Hillsdale, NJ: Lawrence Erlbaum.

Hobsbawm, Eric. 1988 Review of "Cousin Joe: Blues from New Orleans." The [London] Sunday Times, February 7.

Joseph, Pleasant and Harriet Joseph Ottenheimer. 1987. Cousin Joe: Blues from New Orleans. Chicago: University of Chicago Press.

Nurse, Derek. 1989. "Is Comorian Swahili? Being an examination of the diachronic relationship between Comorian and coastal Swahili." In Le Swahili et ses limites. Ambiguite des notions recues. Table ronde internationale du CNRS (Serves, 20-22 avril 1983), edited by M-F. Rombi, pp. 83-105. Paris: Editions Recherche sur les Civilisations. 
Nurse, Derek and Thomas J. Hinnebusch. 1993. "Swahili and Sabaki: A Linguistic History." Linguistics, vol. 121. Berkeley, California, London: University of California Press.

Ochs, Elinor. 1979. "Transcription as Theory." Developmental Pragmatics, edited by Elinor Ochs and Bambi B. Schieffelin, pp. 43-72. New York: Academic Press.

Ottenheimer, Harriet Joseph. 1986. "Shinzwani-English Dictionary with English-Shinzwani Finderlist." Manhattan, KS: SASW/Comorian Studies, on diskette, 596,000 bytes.

Ottenheimer, Harriet Joseph and Martin Ottenheimer. 1976. "The Classification of the Languages of the Comoro Islands." Anthropological Linguistics 18(9):408-415.

Powers, Willam K. 1990. "Comment on the Politics of Orthography." American Anthropologist, I, 92:496-497.

Preston, Dennis R. 1982. “Ritin' Folklower Daon 'Rong: Folklorists' Failures in Phonology." Journal of American Folklore, 95(377):304-326.

Southern, Eileen. 1988. Review of "Cousin Joe: Blues from New Orleans." The Black Perspective in Music, 17(1\&2):194-195.

Tedlock, Dennis. 1983. The Spoken Word and the Work of Interpretation. Philadelphia: University of Pennsylvania Press.

West, Candace. 1996. "Ethnography and Orthography: A (Modest) Methodological Proposal." Journal of Contemporary Ethnography 25(3):327-352. 